to this dilemma is urgent." Does not the answer lie in breaking the link between salary scales and Salmon grades? I grant that the nursing care of (say) 1,000 patients is a greater responsibility than the care of (say) 30 , so it seems reasonable to me that a Salmon 10 should be paid more than a Salmon 6.

The Salmon 7 post seems to me to be an important advance. I picture it as equivalent to the command of a destroyer flotillastill a small-ship man, still close enough to the sea to be soaked in salt water, yet assuming a larger responsibility than that borne by the captain of a single ship. A Salmon 7 is still a bedside nurse yet has a responsibility for more than the patients of just one ward. It is a pity that those who choose to remain in the grade of unit nursing officer (Salmon 7) should find that their increasing experience is rewarded by an increasing gap in remuneration between themselves and those of their contemporaries who use the seventh rung of the nursing ladder to climb to 8,9 , and 10 in nursing administration.

Break the link between pay scales and Salmon structure and I believe we have an answer to the urgent question you pose. By all means let the greater administrative responsibility be recognized at its true worth. But let us also recognize that increased experience of bedside nursing deserves a long incremental salary scale. The "drift into administration" must be stopped if only because drifters are unlikely to make good administrators.-I am, etc.,

Ipswich, Suffolk

R. M. Mayon-White

SIR,-How refreshing to read such a stimulating concept of modern nursing organization. Dr. Ian Haslock's experience of Salmon (14 October, p. 106), however interesting, appears to be somewhat limited, as in some other hospital groups he would find No. 7s functioning exactly as Salmon had intended. If they are "homeless" it could be the fault of management in not providing the necessary accommodation, which the Salmon report stressed as essential if these officers are to fulfil their proper role. We seem to remember the same caustic comments being made about the pre-Salmon assistant matrons.

"Nursing is, by definition, clinical." We agree wholeheartedly. Would Dr. Haslock agree that any organization is only as good as the officers in post? Would he also agree that nursing policy has to be formulated? That the voice of nursing should be heard at top management level? To whom would he give these responsibilities? Hospital management committees? Administrative staff? Medical staff? Then, of course, there is nursing research. Any such teams with whom we have worked have always been most grateful for the assistance given by senior nurses with a particular interest in this area.

We feel that the motive behind this article was to promote discussion rather than to be taken literally, and we agree that we would like to see a better clinical career for the nursing profession. Discussions are afoot as to the possibility of the appointment of nursing specialties. As this position would encourage the expert nurse to remain in the clinical field it should be very well received by all concerned, but-we wonder.
There are points which we can disprove if we felt these were serious comments, but owing to the light-hearted composition of some parts of his "personal view" we feel that Dr. Haslock is a charmingly humorous person whom we would be delighted to meet should he chance in our area. We migh even manage a sip of sherry.-We are, etc.

M. M. MARKLAND Senior Nursing Officer

J. NORTHAM Job Analyst

Royal Infirmary, Bolton

SIR,-I was delighted to read the Personal View by Dr. Ian Haslock (14 October, p. 106) about the implementation of Salmon It is surely time that we took stock of the situation or we may find ourselves without any practical nurses in the years to come. I am, etc.,

Wythenshawe Maternity Hospital,

Pearl A. WALKer Mancheste:

\section{Infertility after the Pill}

SIR,-Your truly excellent leading article on infertility after the pill (14 October, p. 59) prompts me to write against prescribing pills containing higher doses of progestogens with oestrogens in the hope of obtaining withdrawal bleeding in post-pill amenorrhoea. They are even more commonly used in an attempt to diagnose or to exclude pregnancy.

You surmise, probably correctly, that "post-pill amenorrhoea is the consequence of hypothalamic assault by synthetic sex hormones." To give to these patients or to any others in whom the amenorrhoea may be hypothalamic in origin the two-day or the three-day "treatment" or "test," as marketed by several pharmaceutical houses, is to add assault to assault. In many patients in whom the hypothalamic or endocrine disturbance is marked bleeding will not occur after these pills, and the endocrine investigation of the patient must be delayed until the synthetic hormones are completely excreted or detoxicated.

If in the natural course of events a period was due to start it will almost certainly be further delayed by the pills, thus increasing the patient's anxiety. The pills may cause some softening of the cervix, making bimanual exclusion of early pregnancy more difficult. even for the expert. If the patient is really pregnant the progestogens given early in pregnancy may exert a masculinizing effect on a female fetus, and the oestrogens themselves are not harmless to the mother nor possibly to her fetus, for cases have been reported of girls in early adolescence developing carcinoma of the vagina when their mothers were given oestrogens-admittedly in high doses-in early pregnancy.

Testing an early morning sample of urine for pregnancy by one of the newer immunological methods is far more rapid and certain and it is harmless, which the higher dose pills are not always. This is a plea to have these pills withdrawn.-I am, etc.,

E. E. PHILIPP

\title{
Functions of G.M.C.
}

SIR,-You will have seen recent press reports and correspondence on the dissatisfaction of the medical profession with the General Medical Council. This loss of faith was precipitated by enabling legislation which led the G.M.C. to impose an annual registration or retention fee on doctors who had paid a fee which was to secure their registration for life and has been accentuated by rapid increases on the fee far in excess of normal inflation.

Though the G.M.C. has taken steps to improve its financial management root causes of the G.M.C.'s difficulties remain and arise from a failure to reconsider its function in the light of contemporary thought and practice. The G.M.C. was set up by the Medical Act of 1858,14 years before universal education in this country. Apart from small changes brought about by Amending Acts, there has been no major review or inquiry into the G.M.C.'s function, 114 years later. This contrasts with numerous examinations of the organization of the National Health Service and its projected upheaval 26 years after its inception.

We, the undersigned senior staff of the Swindon group of hospitals, ask your assistance in pressing for an independent inquiry into the functions and financial affairs of the General Medical Council.-We are, etc.

V. D. JONES

H. C. DRYSDALE R. B. ROE

R. MARTLEW

F. C. RODGER

K. I. SHIMMINGS A. C. Buck J. F. CAM

M. C. T. MORRISON P. H. DENTON J. A. AgER

E. J. C. WYNNE

A. G. FREEMAN D. W. HIDE

J. A. WADDELL K. D. CROW

Swindon, Wilts

\section{Wrong Target}

SIR.-Squabbles within the profession are rarely becoming. The result is usually further State control to the detriment of all dactors while the patient is more likely to suffer than benefit. The present dispute between the G.M.C. and members of the profession (unspokenly backed by the B.M.A.) is no exception. Of course it was wrong for the G.M.C. to renege on the original contract of a life payment in favour of an annual retention fee. Nevertheless, the principle of an initial once-only payment was unrealistic. Even modest inflation would require an inordinately high figure to be paid by the doctor when he could least afford it. Retention fees exist for most professions in Great Britain and for doctors in many other countries.

Though the G.M.C. exists to protect the public it is superficial and naive to suppose the public should pay. The profession must be responsible for maintaining its own standards of teaching and integrity, but the G.M.C. will have to alter its au+ocratic attitude to regain the doctors' respect. It and 